\title{
A SEÇÃO O PORTUGUÊS É UMA FIGURA EM DIÁLOGO COM GÊNEROS DISCURSIVOS NA ESFERA JORNALÍSTICA
}

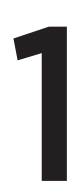

\section{THE SECTION "PORTUGUESE IS A FIGURE" IN DIALOGUE WITH DISCURSIVE GENRES \\ IN JOURNALISM}

\section{BORGES, Marilurdes Cruz}

Doutora em Linguística e Língua Portuguesa pela UNESP-Araraquara

Docente do Programa de Pós-Graduação em Linguística da Universidade de Franca -UNIFRAN

E-mail: marilurdescruz@gmail.com

\section{BATISTA, Juliana Spirlandeli}

Doutora em Linguística e Língua Portuguesa pela UNESP-Araraquara

Docente e Coordenador dos cursos de Letras e Pedagogia da Universidade de Franca - UNIFRAN

E-mail: juspirlandeli@hotmail.com

\section{RESUMO:}

O presente artigo apresenta um estudo acerca de gêneros discursivos comuns à esfera jornalística, a fim de observar como eles se manifestam nessa esfera e como a seção O português é uma figura, publicada da revista Língua Portuguesa com eles dialoga. Para desenvolver essa análise, utiliza-se, por pressuposto teóricos, os pensamentos do Círculo de Bakhtin no que se refere às relações dialógicas e gêneros discursivos. Expõe-se, inicialmente, as reflexões sobre esfera de atividade e gêneros do discurso, a fim de compreender o projeto de dizer próprio da esfera jornalística. Foram selecionados quatro enunciados publicados na seção em estudo para desenvolver a análise e observar como os diálogos se constroem na materialidade linguística e como, discursivamente, eles respondem às intenções enunciativas da esfera jornalística.

Palavras-chave: diálogo; gêneros discursivos; esfera jornalística.

\section{ABSTRACT:}

The article presents an study on the discursive genres which are common in journalism, with the aim of observing how they act 
in this area e how the section "Portuguese is a figure", published in Língua Portuguesa magazine, dialogues. For the development of this analysis, we are based on the theory of the bakhtinian circle, referring to the dialogycal relations and discursive genres. Initially, we expose the reflections on the activities and the discursive genres, in order to comprehend the project of saying typical of the journalism. We selected four enunciates published in the section under study to develop the analysis and observe how the dialogues are built in the linguistic materiality and how, discursively, they respond to the enunciative intentions of the journalism.

Keywords: dialogue; dicursive genres, journalism.

O presente artigo é parte da tese de doutorado intitulada Gêneros do discurso em diálogo na seção o Português é uma figura: o jornalístico, o científico e o pedagógico, no discurso de Marcílio Godoi, na revista Língua Portuguesa, defendida em julho de 2015. Neste artigo, apresentamos um estudo sobre os gêneros discursivos que circulam na esfera jornalística e como o corpus com eles dialogam.

Os pressupostos teóricos que norteiam nossas investigações partem dos pensamentos bakhtinianos, os quais consideram ser todo procedimento discursivo englobado pelo dialogismo. Para Bakhtin (2000), a linguagem só é dotada de sentido, se houver, no discurso entre sujeitos, a possiblidade de interação verbal. Em decorrência disso, o locutor e o interlocutor são de extrema relevância, visto que "toda enunciação é uma 'resposta', uma réplica, a enunciações passadas e a possíveis enunciações futuras e, ao mesmo tempo, uma 'pergunta', uma 'interpelação' a outras enunciações" (SOBRAL, 2009, p.33).

O conceito de diálogo, nos estudos do Círculo de Bakhtin, referese à condição de composição de enunciados e discursos, ou seja, a condição de como e de onde os sujeitos agem e com quem eles se interagem ao produzirem seus enunciados (SOBRAL, 2009). Não há, pois, um texto desconectado do contexto, já que o dispositivo enunciativo é a condição, o motor e o ambiente de toda enunciação.

Partindo desse conhecimento, todo enunciado é, portanto, um objeto formado por muitas vozes que se entrecruzam e se completam, por isso, estudá-lo requer compreender as forças vivas das quais ele surge e nas quais ele atua. O sentido de um enunciado se constrói tanto pelo ato responsável dos interlocutores quanto pelos valores ideológicos 
instaurados pelas esferas de atividade.

As esferas de atividade são compreendidas como campos de produção ideológica, ou seja, campos de legitimação, de regularização e de significação das interações sociais como: ciência, educação, arte, jornalismo, religião, entre outras.
A noção de esfera de comunicação discursiva (ou da criatividade ideológica, ou da atividade humana, ou da comunicação social, ou da utilização da língua, ou simplesmente ideologia) é compreendida como um nível específico de coerções que, sem desconsiderar a influência da instância socioeconômica, constitui as produções ideológicas segundo a lógica particular de cada esfera/ campo (GRILLO, 2016, p.43).

De acordo com os estudos do Círculo de Bakhtin, compreende-se que cada esfera de atividade tem sua própria função no conjunto da vida social, pois os signos ideológicos não apenas refletem a realidade, mas a refratam através de fragmentos de materiais dessa realidade (BAKHTIN/ VOLOCHÍNOV, 2010, p.33). Cada esfera conhece e reconhece os gêneros apropriados à sua especificidade e modalidade estilística e determina concepções de sentido da palavra, tanto para o locutor quanto para seu interlocutor. Por isso, "cada gênero do discurso, em cada campo da comunicação discursiva, tem a sua concepção típica do destinatário que o determina como o gênero" (BAKHTIN, 2000, p. 147).

Para que um enunciado se insira em uma determinada esfera de atividade, é necessário que haja o conhecimento e a atualização dos gêneros, pois cada esfera possui "uma linguagem própria que nomeia e classifica os agentes e produtos, com o intuito de construir hierarquias e modos de percepção" (OLIVEIRA, 2012, p. 165). Além disso, é preciso também compreender que o enunciado concreto, para Volochínov/ Bakhtin (1976, p.8), "sempre une os participantes da situação comum como co-participantes que conhecem, entendem e avaliam a situação de maneira igual".

Todo enunciado é um projeto intencional, elaborado por um sujeito em uma dada situação de enunciação. Desse modo, no projeto enunciativo, conectam-se tanto o objeto de sentido, o tema e a forma composicional, quanto as circunstâncias concretas de produção desse enunciado. Assim, os gêneros do discurso dizem respeito aos atos de atividade e às relações dialógicas do processo comunicativo. Eles devem, portanto, serem observados na dimensão do tempo e do espaço onde as interações se produzem e articulam formas discursivas criadoras 
da linguagem, de visões de mundo e de sistema de valores configurados por pontos de vista determinados.

Nenhum gênero surge do nada; ele se liga necessariamente a uma tradição. E essa tradição que permite estudar qualquer gênero do ponto de vista diacrônico (os gêneros que o antecedem, aos quais ele se liga e ao mesmo tempo modifica) e sincrônico (características pertencentes aos gêneros antecedentes e, ao mesmo tempo, as novas características que o definem e diferenciam dos antecessores) (BRAIT; PISTORI, 2012, p.375).

A escolha do gênero depende das necessidades do tema e das especificidades de determinada esfera da comunicação verbal em que o enunciado se encontra. Então, ao se analisar o enunciado concreto, é preciso considerar a esfera da comunicação em que ele está inserido, a fim de reconhecer o gênero discursivo em sua relação com o contexto histórico.

O locutor e seu interlocutor devem conhecer as esferas de uso da linguagem e observar como se constroem as relações dialógicas do enunciado e como ele se configura em função do sistema de signos que o realiza. Em algumas situações, o enunciado pode adquirir uma outra concepção de gênero ou apresentar uma intergenericidade - o diálogo entre gêneros ou a evidência de diferentes gêneros em um mesmo enunciado.

Assim, os gêneros do discurso podem apresentar certa estabilidade enunciativa, mas também podem apresentar novas formas de estratificação discursiva, seja por meio do aparecimento de um novo gênero, seja pela intergenericidade. "Ao nascer, um novo gênero nunca suprime nem substitui quaisquer gêneros já existentes. Qualquer gênero novo nada mais faz que completar os velhos, apenas amplia o círculo de gêneros já existentes" (BRAIT; PISTORI, 2012, p. 377).

\section{GÊNEROS DISCURSIVOS NA ESFERA JORNALÍSTICA}

Como nossa investigação parte do diálogo da seção $O$ português é uma figura com a esfera jornalística, faz-se necessário conhecer as particularidades enunciativas e valorativas dessa esfera, bem como alguns gêneros comuns a ela, com os quais o corpus de análise também dialoga.

A esfera jornalística é determinada por cinco coerções: "a atualidade, a periodicidade, a objetividade, a informatividade e captação do leitor" (GRILLO, 2006, p.153). Cabe a essa esfera oferecer 
informações reais e relevantes sobre todas as áreas do conhecimento humano, utilizando-se, por estilo, a clareza e a transparência.

A esfera jornalística propõe oferecer informações 'verdadeiras' e mais próximas da realidade vivenciada pelo seu interlocutor, por meio de diferentes gêneros discursivos como a reportagem, a notícia, a entrevista, a carta ao leitor, a carta do leitor, a crônica, dentre outros. Em si, o jornalismo é visto "como uma atividade complexa que envolve processos de difusão (notícia, informação), interpretação, análise (reportagem), argumentação (opinião) e reflexão (crônica, comentário)" (CRISTÓVÃO, 2011, p. 41).

A seção O português é uma figura, produzida por Marcílio Godoi, passou a integrar a revista Língua Portuguesa a partir da edição n.31, em maio de 2008. Essa seção, publicada sempre na última página (p.66), apresenta, a cada mês, um enunciado que traz informações e reflexões sobre um artista/escritor de língua portuguesa. Os sujeitos expostos na seção são sujeitos já consagrados, validados e reconhecidos pelo público leitor por criarem discursos artísticos. Neste artigo, esses sujeitos serão nomeados de autor.

A proposta da seção é traçar o perfil de um autor e destacar os mecanismos linguísticos e artísticos utilizados por ele em sua construção textual e discursiva. Assim, a criação enunciativa da seção decorre dos diálogos travados com os mundos artístico, científico e cotidiano que, direta ou indiretamente, participam da maneira com que o autor vê e sente as diferentes manifestações da língua/linguagem e que, consequentemente, extravasa em sua poeticidade.

Ao investigar a forma composicional da seção, observa-se que o layout é sempre o mesmo: A seção é intitulada de $O$ português é uma figura, mas a cada publicação ela traz um título para apresentar o autor do mês. Há, em sua composição, um desenho, uma citação e uma pequena apresentação do perfil do autor. Essas três partes dialogam entre si, com enunciados outros e com as esferas jornalística, científica e educacional, produzindo sentidos e valores ao autor e ao enunciado instaurado na seção.

A área do conhecimento que se produz a seção é a artística, pois, além de destacar um artista - escritor de textos artisticamente produzidos - o enunciador da seção recria sujeitos/heróis por meio de uma elaboração poética. O trabalho estético pode ser visto na construção do título, nos traços que compõem o desenho, nos recortes das citações, nas escolhas estilísticas que traçam o perfil dos autores e na disposição 
das partes que contemplam o enunciado. Portanto, é uma materialidade que se preocupa com o valor estético.

A seção O português é uma figura dialoga com a esfera jornalística não só porque está publicada na revista Língua Portuguesa, mas porque responde a alguns elementos próprio dessa esfera como veremos a seguir:

Desde que iniciou sua participação junto à revista Língua Portuguesa, em maio de 2008, a seção, de Marcílio Godoi, foi publicada em todos os periódicos, em um local específico - a última página -, fato este que mostra sua regularidade e periodicidade. Ela traça perfis de autores de diferentes épocas e contextos enunciativos, embora privilegie os contemporâneos. Independente da época em que o autor viveu e produziu sua obra, o enunciador procura atualizá-lo e mostrar ao leitor que as visões de mundo e as maneiras de manifestar-se linguisticamente não são específicas de um único indivíduo em um determinado tempo específico, pois ilustram e representam realidades sócio-discursivas. Tanto a preocupação enunciativa em atualizar e contextualizar os discursos promovidos na seção, quanto sua periodicidade caracterizam atitudes responsivas, portanto, dialógicas, junto à esfera jornalística.

A objetividade, outro requisito da esfera jornalística (e que se obtém a partir de recursos como uso de terceira pessoa do singular, uso do discurso direto e indireto, etc.) não é predominante na seção, no entanto, ela se entrevê em alguns recursos utilizados. Embora se perceba a subjetividade no desenho e na citação, já que evidencia as escolhas do enunciador e sua forma de ver e reconhecer o autor, na parte destinada à apresentação do perfil dos autores, há efeitos de objetividade. Nessa parte, o enunciado aparece, normalmente, na terceira pessoa do singular ou na primeira pessoa do plural, o que mostra algum distanciamento/ afastamento do enunciador. Além desses recursos, destaca-se o emprego do discurso citado em sua forma em que "é visto pelo falante como a enunciação de uma outra pessoa, completamente independente na origem, dotada de uma construção completa, e situada fora do contexto narrativo" (BAKHTIN, 2010c, p. 150). Assim, o discurso citado aparece na materialidade discursiva por meio do discurso direto e indireto, em que outras vozes enunciativas são ouvidas junto à voz do enunciador.

O interlocutor/leitor é elemento primordial da esfera jornalística, pois o enunciado só se concretiza e se propaga por meio dele, no entanto, como a seção em estudo apresenta um discurso artístico, destina-se a um tipo específico de leitor, do qual procura captar a atenção e com o qual estabelece relações dialógicas. O leitor da seção $O$ português é uma 
figura não é um leitor comum, um leitor que aprecia qualquer tipo de informação. É um tipo de leitor que se interessa pela linguagem, que procura compreender os mecanismos de construção dos enunciados, que busca prazer na palavra trabalhada, arquitetada, elaborada, mesmo que na mais simples manifestação cotidiana. É, portanto, o consumidor de diversas modalidades discursivas comuns ao chamado jornalismo cultural, bem representado pela revista Língua Portuguesa.

Os gêneros discursivos que circulam na esfera jornalística abordam temas relativos a acontecimentos presentes ou que estão prestes a ocorrer, e que, de algum modo, influenciarão a vida dos leitores, mas também há gêneros, nessa esfera, que estabelecem elos com o passado, dialogando com a memória cultural. Assim, partindo do conhecimento de que "o gênero vive do presente, mas recorda o seu passado, o seu começo" (BAKHTIN, 2000, p. 159), compreendemos que o acontecimento do passado enunciado em determinado gênero, nessa esfera de atividade, será atualizado, ou seja, adquirirá, no contexto de enunciação e nas relações dialógicas estabelecidas, um novo enunciado.

Dos gêneros comuns à esfera jornalística, que comumente priorizam os processos enunciativos de difusão, interpretação, análise e reflexão, abordaremos a biografia, o perfil, a reportagem e a crônica, a fim de investigar seus elementos enunciativos e observarmos se a seção O português é uma figura com eles dialoga; e se dialoga, como empreende a eles uma resposta.

A biografia é um gênero discursivo cujo acontecimento é apreendido pela história, por isso, alguns estudiosos chamam-na de "gênero de memória" (DIAS, 2001). "De origem grega, a palavra biografia é formada pelos radicais "bio" (vida) e "grafia" (escrever); significa escrever ou descrever a vida de alguém que foi relevante à determinada sociedade" (HOUAISS, VILLAR, FRANCO, 2009, p.292). A biografia é um gênero de caráter narrativo que, comumente, apresenta a história da vida de um sujeito que já morreu e já foi reconhecido pela sociedade, mas nada impede que ela também narre a história de uma pessoa viva (SILVA, 2009).

A construção de uma biografia exige diálogo com as diferentes formas de controle simbólico do tempo e da individualização nas sociedades humanas, na busca de traduzir uma experiência de duração e estruturas imaginativas que relacionam uma vida e suas relações com a cultura na qual se insere na "vida póstuma", na qual mortos e vivos dialogam a partir das heranças dos primeiros e das carências dos segundos (SILVA, 2009, p. 153). 
No passado, a biografia era chamada de historiografia ou crônicas, pois eram produzidas por historiadores ou cronistas que desejavam documentar, por meio do ato de narrar, fatos de uma época através da história de um indivíduo importante cuja trajetória de vida contribuísse à formação cultural de um povo.

A biografia é um gênero que dialoga com outros gêneros porque utiliza recursos de várias áreas do conhecimento como da história, da literatura e do jornalismo (PEREIRA, 2007). Tem gênese literária porque $\mathrm{o}$ ato narrado adquire aspecto ficcional, embora sempre haja "tensão entre a vontade de reduzir um vivido real passado, segundo as regras da mímesis, e o polo imaginativo do biógrafo, que deve refazer um universo perdido segundo a sua intuição e talento criador" (DOSSE, apud FONSECA, VIEIRA, 2011, p.105). Quando a biografia é publicada na esfera jornalística, adquire um caráter de atualidade e tem por objetivo recuperar, resgatar e ressignificar a história do sujeito biografado.

A memória é a construção de um ponto de vista sobre uma dada realidade em que passado e presente se encontram e são (re)significados pelo sujeito a partir desse ponto de vista. A memória não é assim um produto do passado, mas um processo de (re)significação desse passado à luz do presente (DIAS, 2001, p. 148).

É nesse sentido que a história de vida de um sujeito se atualiza, pois, ao ser recuperada e resgatada da história e da memória, é ressignificada pelo olhar de quem a conta e de quem a lê. No jornalismo, a biografia também é "um produto de consonância e dissonância entre o factual e o ficcional, e a subjetividade do relato biográfico e o como dizer esta narrativa se interpõe como imbricações conflitantes do fazer biográfico, como na historiografia" (FONSECA, VIEIRA, 2011, p. 105).

Por isso, segundo Fonseca e Vieira (2011), os jornalistas têm procurado, no gênero biografia, uma nova vertente do gênero reportagem, porque procuram reportar histórias de vidas que pertencem ao imaginário coletivo, como a vida de artista e de políticos. No retrato da trajetória de uma vida, vemos, pois, um novo enfoque, um novo significado, já que nos são apresentadas outras possibilidades dessa trajetória.

Para se produzir uma biografia, o biógrafo deve, inicialmente, desenvolver um trabalho árduo de pesquisa, pois "o compromisso com a realidade exterior à obra e a submissão às chamadas provas de verdade são aspectos essenciais do discurso biográfico" (PENA, 2004, p. 10). Cabe também ao biógrafo selecionar os dados e os acontecimentos mais significativos do biografado, além de construir, por meio da interpretação 
dos fatos, uma narrativa atraente aos olhos do leitor. É, portanto, no modo de investigar, selecionar e organizar as informações que o biógrafo revelará o retrato do sujeito biografado.

Ressaltamos que, na esfera literária, a biografia tem por intento, além de apresentar a vida do escritor, expor um estudo crítico sobre sua obra, conceituá-la, por isso é comum muitos críticos literários explorarem a vida e a obra de grandes escritores através de biografias como, por exemplo, o fez Alcides Maia, na obra Machado de Assis algumas notas sobre o "humor", em que deu ênfase à obra de Machado de Assis, mas não privilegiava aspectos biográficos propriamente dito (PEREIRA, 2007, p. 31). Já na esfera jornalística, a biografia adquire caráter de acontecimento jornalístico, em que o sujeito biografado volta a ser notícia, como aconteceu com a biografia de Maysa Matarazzo, escrita pelo jornalista Lira Neto. A obra Maysa: só numa multidão de amores (2007) "suscitou o interesse da indústria cultural, que fez o relançamento de discos e regravações de suas composições" (FONSECA, VIEIRA, 2011, p. 106). Tal fato acontece porque o projeto de dizer dessa esfera é reportar, informar, propagar e divulgar o sujeito biografado.

Atualmente, as biografias têm sido um gênero bem atrativo aos leitores, pois "o uso de técnicas literárias e de uma linguagem clara e acessível para a maior parte dos leitores (características essa ligada diretamente ao jornalismo), desperta o interesse do leitor, que se sente lendo um romance da vida real" (PEREIRA, 2007, p.35). Por isso, o leitor de biografia busca não só informações sobre o biografado, mas elementos de sua vida que possam lhe servir de modelo, de inspiração, de mecanismos para compreender o mundo e agir sobre ele. Por isso, só se faz uma biografia de alguém que atraia o interesse do leitor.

Conhecidos alguns elementos enunciativos próprios do gênero biografia, achamos que há traços desses elementos no corpus em análise, visto que o projeto de dizer que inferimos na seção é retratar aspectos da vida e da obra de um autor consagrado, ou seja, um sujeito que já pertence ao imaginário coletivo da sociedade brasileira.

Os aspectos da vida e da obra traçados, em cada seção, são retirados do passado histórico e da memória cultural, documentados por meio de estudos críticos ou relatados por pessoas que conviveram com o sujeito biografado. Assim, as vozes detentoras desse saber podem ser ouvidas na materialidade enunciativa de forma explícita ou implícita.

No processo do ato enunciativo, o enunciador seleciona, das informações obtidas, elementos que priorizam dados sobre a produção 
artística, a postura crítica e as escolhas linguísticas mais representativas de um determinado grupo social. Ao fazer suas escolhas e os recortes relevantes ao seu projeto de dizer, interpreta os dados, rearranja-os e organiza-os em um novo contexto, como ilustrado na Figura 1.

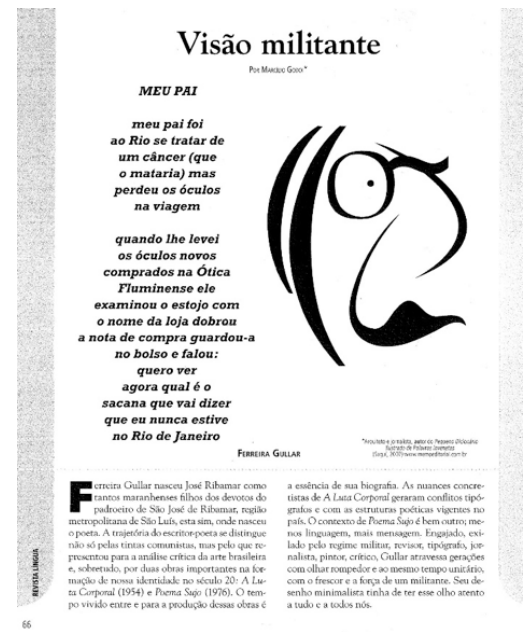

Figura 1.Fonte: GODOI, M. Visão militante. In: O português é uma figura. Língua Portuguesa. Ano III, n.33. p. 66

As informações dos autores, apontadas no enunciado da seção, são atualizadas e ressignificadas pelas mãos do enunciador, cujo projeto de dizer não é meramente apresentar a vida e a obra do artista, mas, a partir dos atos enunciativos dele, abordar aspectos referentes à língua portuguesa e aos procedimentos da linguagem.

No fragmento abaixo, pode-se observar alguns elementos discursivos que evidenciam o projeto de dizer do enunciador e que contribuem para a ressignificação dos valores instaurados pela memória cultural.

O tempo vivido entre e para a produção dessas obras é a essência de sua biografia. As nuances concretistas de A Luta Corporal geraram conflitos tipógrafos e com as estruturas poéticas vigentes no país. O contexto de Poema Sujo é bem outro; menos linguagem, mais mensagem. Engajado, exilado pelo regime militar, revisor, tipógrafo, jornalista pintor, crítico, Gullar atravessa gerações com olhar rompedor e ao mesmo tempo unitário, com o frescor e a força de um militante (Fig.1).

Ao apresentar a obra de Ferreira Gullar, o enunciador destacou 
suas características concretistas, as quais têm por proposta elaborar o poema-objeto, marcado pela valorização acústica e visual, pela vasta carga semântica, pela exploração dos vocábulos e pela disposição geométrica no espaço tipográfico da página. De acordo com a sua fortuna crítica, o experimento linguístico de Gullar "radicaliza-se como impasse, não como afirmação eufórica; a luta corporal com as palavras ressoa o timbre moderno da impossibilidade de expressão" (VILLAÇA, 1998, p.90).

Essas características, na visão do enunciador, não constituem apenas elementos da obra do poeta, mas se inscrevem em sua própria personalidade, visto que "é essência de sua biografia", portanto, de sua história, de sua vida, marcada na sua forma de escrever, de trabalhar e de viver. Em Gullar, os símbolos

são mais que figuras, ou temas: já constituem atitudes, gestos, valores, compromissos fundamentais do sujeito poético consigo mesmo e com o mundo. Passam a simbolizar nexos estruturais entre o indivíduo e a História, a consciência e o tempo, o sentimento de vida e o sentimento de morte (VILLAÇA, 1998, p. 90).

Ferreira Gullar é, portanto, um sujeito da "visão militante", em que experimenta a palavra poética e a palavra político-social até reconstruila através de uma reflexão crítica (TURCHI, 1985). Por isso, chama-nos atenção o dito pelo enunciador da seção: "o tempo vivido entre e para a produção dessas obras é a essência de sua biografia" (Fig. 1). Aqui há explícito o diálogo com o gênero biografia, tanto que é citado na materialidade enunciativa, mas também nos mostra que o contexto vivido - década de 60, ditadura no Brasil, repressão da linguagem está integrado na vida e na produção artística do poeta Ferreira Gullar. Assim, a concreticidade enunciativa do poeta é percebida na vida, nas características estilísticas e na temática abordada em suas poesias.

É, pois, no fazer poético do autor e na exposição e reflexão sobre sua vida e obra, apresentada na coluna de Godoi, que o conhecimento histórico, resgatado pela memória cultural, é ressignificado e atualizado, pois conduz o leitor a outros conhecimentos, outras perspectivas sobre o autor. Conhecer o contexto de produção e fatos que motivam o fazer artístico interferem no sentido empreendido pelo leitor. Portanto, consideramos que a seção $O$ português é uma figura, de Marcílio, ao responder às propostas enunciativas do gênero biografia, com ele dialoga.

Há na esfera jornalística um outro gênero que também se propõe 
a traçar o retrato de um indivíduo, gênero este que é chamado de perfil. Segundo Vilas Boas (2004, p. 91), "o perfil jornalístico é um texto biográfico curto (também chamado de short-term biography) publicado em veículo impresso ou eletrônico, que narra episódios e circunstâncias marcantes da vida de um indivíduo, famoso ou não".

Nesse gênero, cabe ao enunciador dar pleno destaque à personagem cuja vida é traçada. Para tanto, o enunciador deve relacionar-se com ela, estudá-la profundamente para que juntos construam um perfil da vida da personagem, mas que também atenda aos interesses do enunciador. A intenção enunciativa do perfil não é idealizar a personagem, mas humanizá-la em sua singularidade humana (VILAS-BOAS, 2004).

O perfil apresenta, normalmente, narrativas sintéticas que mostram apenas trechos de uma história de vida, os quais evidenciam a forma de pensar da personagem, podendo se ligar ou servir aos conceitos e valores que interessam ao enunciador e que são atualizados pelo contexto enunciativo. Sodré e Ferrari (1989) consideram que, nos gêneros notícia, entrevista e reportagem, é possível ver traços do gênero perfil.

Como o que diferencia o gênero perfil do gênero biografia é seu caráter sintético, podemos constatar que a seção de Marcílio Godoi também dialoga com esse gênero. Cabe aqui destacar que há evidências de diálogo da seção com o gênero perfil, pois a exposição sobre a vida e obra do autor aparece em apenas três ou quatro parágrafos. Na perspectiva do gênero perfil, é compreensível chamar os autores apresentados na seção em estudo de heróis/personagens, já que essas não são meramente representadas, elas são recriadas, ressignificadas nesse novo contexto de enunciação.

Tais fatos podem ser comprovados pelo título dado às seções e pelos desenhos dos autores, pois evidenciam o olhar do enunciador sobre as marcas estilísticas e linguísticas do sujeito cujo perfil é traçado. Ao enfatizar características dos artistas na escrita do colunista, o editor da revista Língua Portuguesa destaca os procedimentos estilísticos do enunciador que busca, a cada seção, aproximar-se ao máximo do autor cujo perfil é traçado. Essas marcas enunciativas são visíveis nas materialidades enunciativas e explicitam as relações dialógicas instauradas pelas vozes que circundam a seção. Desse modo, tanto o enunciador quanto o leitor participam das propostas enunciativas do autor e com ele dialogam e a ele respondem.

É preciso, no entanto, observar que a voz sobreposta e a adaptação estilística não significam que o enunciador se ausenta totalmente de 
seu enunciado, pois há, na exposição sobre os autores, interpretações e ressignificações elaboradas por ele, já que é o enunciador quem seleciona, recorta, organiza e expõe ideias e juízos de valor. Portanto, enfatizar o estilo do autor faz parte do projeto de dizer da seção que tem por intuito levar o leitor a refletir sobre as manifestações da língua e procedimentos da linguagem em diversas situações de enunciação, conforme é possível observar na Figura 2.

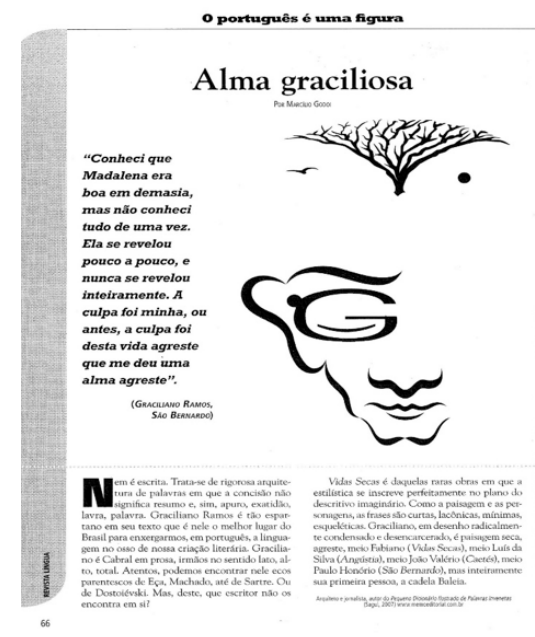

Figura 2. Fonte: GODOI, M. Alma graciosa. In: O português é uma figura. Língua Portuguesa. Ano 4, n.56, jun. 2010, p. 66.

A fim de ilustrar as marcas estilísticas do autor no enunciado, destacamos um fragmento do perfil traçado de Graciliano Ramos.

Nem é escrita. Trata-se de rigorosa arquitetura de palavras em que a concisão não significa resumo e, sim, apuro, exatidão, lavra, palavra. Graciliano Ramos é tão espartano em seu texto que é nele o melhor lugar do Brasil para enxergarmos, em português, a linguagem no osso de nossa criação literária (Fig. 2).

A aridez comum ao estilo de Graciliano Ramos e ao cenário constante de suas obras pode ser observada, no enunciado da seção, por meio da segmentação dos substantivos atribuídos à escrita do autor em "a concisão não significa resumo e, sim, apuro, exatidão, lavra, palavra" (Fig. 2). Esses elementos também ilustram as reflexões sobre os procedimentos linguísticos, já que esses são adaptados às situações da seca, da paisagem hostil, responsável pela condição de vida das 
personagens de Graciliano, como disse Paulo Honório em São Bernardo: "A culpa foi minha, ou antes, a culpa foi desta vida agreste que me deu uma alma agreste" (Fig. 2). Portanto, em Graciliano, temos a linguagem árida porque o meio é árido, a fome e a miséria física cotidiana manifestamse no sentimento, no modo de pensar e de falar. É, pois, esse o projeto de dizer da seção: traçar o perfil do autor e levar o leitor a compreender mais que sua vida e sua obra, compreender as modalidades discursivas e enunciativas em diversos contextos de enunciação.

A reportagem é outro gênero comum à esfera jornalística, pois tem caráter informativo. Sua função primordial é reportar, por meio do ato de narrar, um acontecimento repercutido no organismo social, ou seja, na realidade, descrevendo-o. Não cabe à reportagem analisar ou avaliar o conteúdo da informação, mas pode revelar ângulos insuspeitos e conduzir o leitor a um posicionamento crítico (MENDONÇA; CAVALCANTI, 2011).

Geralmente, a reportagem narra um acontecimento de forma cronológica e, normalmente, vem acompanhada de outros gêneros (foto, gráfico etc.). $\mathrm{O}$ acontecimento relatado pela reportagem não se refere a um ato pontual ocorrido em determinado momento do passado, mas refere-se a um ato em processo, em construção, o que lhe dá um caráter de atualidade (MELO, 1985). Embora o enunciado se proponha à objetividade, o acontecimento é narrado a partir do ângulo do sujeito enunciador, mesmo que ele compartilhe seu enunciado com outros sujeitos, outras vozes discursivas postas por meio do discurso direto e indireto.

O ato de narrar um acontecimento extraído do organismo social, acontecimento que gera interesse do público, é um dos fatores primeiros que nos faz pensar no possível diálogo do corpus com esse gênero, já que a seção narra alguns aspectos da vida e da obra de um autor, extraídos da memória cultural, portanto, retirados do organismo social.

Mesmo que a reportagem não avalie explicitamente (ou de forma incisiva) o acontecimento, ela pode revelar fatos invisíveis a olhos nus, ou seja, abordar elementos enunciativos que despertem curiosidades e promovam novos conhecimentos ao leitor. Esse aspecto também nos leva a pensar nos atos responsivos do enunciador da seção, pois os enunciados das seções procuram narrar e reportar fatos da vida e da obra do autor que, mesmo pertencente à memória cultural, ressaltam particularidades pouco exploradas ou dão a elas novas perspectivas, visto que são escolhas do autor-criador e servem ao seu projeto de dizer. 
A relativa objetividade proposta também por esse gênero é um aspecto que encontramos no corpus, pois, mesmo que a vida e a obra do autor sejam narradas e interpretadas pelo enunciador, ele se coloca, na maioria das vezes, na $3^{\text {a }}$ pessoa do singular e compartilha seu enunciado com outras vozes enunciativas, como já apontamos anteriormente e aparece na Figura 3

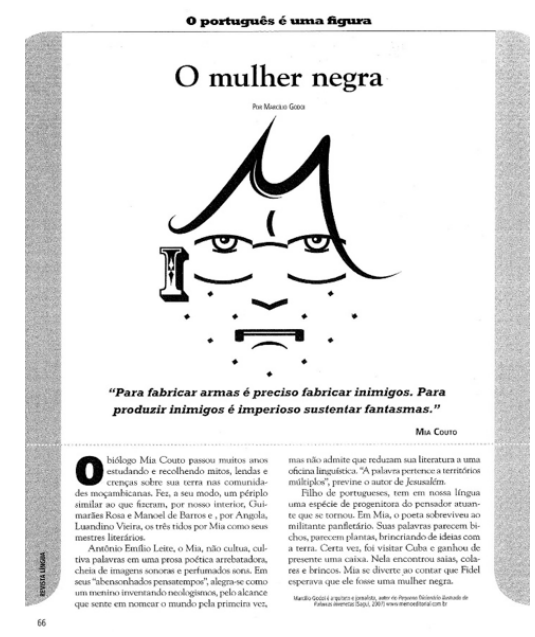

Figura 3.Fonte: GODOI, M. O mulher negra. In: O português é uma figura. Língua Portuguesa. Ano III, n.33. p. 66.

Ilustramos abaixo um fragmento que narra a vida e a obra de Mia Couto (Fig.3) para, a partir dele, destacarmos elementos que possam nos mostrar os atos responsivos ao gênero reportagem.

Antônio Emílio Leite, o Mia, não cultua, cultiva palavras em que uma prosa poética arrebatadora, cheia de imagens sonoras e perfumados sons. Em seus "abensonhados pensatempos", alegra-se como um menino inventando neologismos, pelo alcance que sente em nomear o mundo pela primeira vez, mas não admite que reduzam sua literatura a uma oficina linguística. "A palavra pertence a territórios múltiplos", previne o autor de Jerusalém (Fig.3).

A história de Mia Couto é-nos relatada por meio de sua obra, marcada pelo trabalho estético - imagens sonoras e perfumados sons. O seu ato de narrar é recheado de neologismos, os quais o enunciador da seção destaca: "abensonhados pensatempos". Aproximando-se do escritor, o autor-criador, ao mesmo tempo em que expõe uma preocupação do autor, atiça a curiosidade do leitor, pois chama-lhe a 
atenção sobre os procedimentos enunciativos e construtivos de sua obra: "não admite que reduzam sua literatura a uma oficina linguística". Ao destacar a negativa do próprio autor, o leitor é despertado e instigado a observar as particularidades das construções linguística de suas narrativas, propósito primeiro do projeto de dizer da seção.

Uma abordagem inovadora sobre o autor e que leva o leitor a ativar sua memória cultural é chamá-lo de "o autor de Jerusalém". Tal designação nos provoca pensamentos múltiplos que não são respondidos na coluna, mas que são reportados e promovem a curiosidade do leitor para compreendê-la através de sua obra. Os leitores, assim, são motivados a desvendar a palavra de Mia Couto, como ele mesmo nos disse "A palavra pertence a territórios múltiplos".

A crônica é um gênero discursivo que pode adquirir caráter histórico, poético e jornalístico. "De origem grega, a palavra crônica deriva do termo chronos que significa, na mitologia grega, tempo cronológico ou sequencial. Por isso, cabe a ela registrar um acontecimento em um intervalo de tempo" (HOUAISS, VILLAR, FRANCO, 2009, p.577).

É, portanto, um tipo de enunciado construído pela observação do real por meio de olhos investigativos, os quais procuram ir além do registro de um fato ocorrido porque buscam seus significados no comportamento humano.

As primeiras crônicas em língua portuguesa foram escritas na Idade Média e tinham caráter histórico, por isso eram chamadas de crônicas históricas. Para elaborá-las, o cronista se colocava na posição de observador da cena histórica, a partir do que via ou do que colhia em fonte de referência, e relatava as circunstâncias sobre o acontecimento, sobre o cenário e sobre os sujeitos que os vivenciaram (MELO, 2002).

Fernão Lopes, considerado o primeiro cronista da língua portuguesa, foi encarregado de escrever as histórias dos reis e do passado português. Também, os primeiros relatos sobre o Brasil foram escritos por cronistas, que eram contratados e encarregados de informar a coroa portuguesa sobre as descobertas ultramarinas. Esses dois exemplos confirmam o objetivo do gênero, já que registram fatos históricos.

Mas esse conceito de crônica, com o advento da literatura jornalística no século XIX, sofre uma ressignificação, pois junto às informações e descrições históricas, insere-se o registro do cotidiano, além de também apresentar, às vezes, um caráter ficcional. Assim, o cronista do século XIX, inserido na esfera jornalística por meio dos folhetins, adquire outros objetivos e função, passando a escrever textos 
que abordam os hábitos e costumes da sociedade a fim de entreter o público leitor.

No Brasil, a crônica aparece pela primeira vez em 1828, "no jornal Espelho Diamantino, em que lançou a ideia de que todo jornal deveria contar com um observador de costumes, que registrasse o que visse e ouvisse em suas andanças pelas ruas da cidade" (COSTA, 2005, p.247). Há, porém, pesquisadores que afirmam que o gênero realmente se efetiva em 1854, "quando José de Alencar publicou o primeiro folhetim da série "Ao correr da pena", no jornal Correio Mercantil" (SANTOS, 2005, p.16).

Ao ser inserida na esfera jornalística e se propor a relatar fatos extraídos do cotidiano para entreter o leitor, a crônica adquire caráter poético-jornalístico.

Sendo a crônica o resultado de uma prática de escritores nos domínios do jornal, ela tem forçosamente componentes híbridos, ou seja, os poéticos, organizados a partir de uma visão subjetiva do mundo, gerados por um investimento figurativo na linguagem, e um outro, mais referencial, gerado pela exigência do veículo impresso destinado a um público heterogêneo (MOURA, 2008, p. 3).

A partir do século XIX, muitos escritores de literatura passaram a contribuir periodicamente no jornalismo por questões de subsistência e para divulgar seu trabalho artístico, embora esse, inserido na esfera jornalística, tenha se adaptado às necessidades discursivas e ideológicas dessa esfera. Na esfera literária, o escritor produz, em torno da atividade da escrita, sua identidade, visto que a história narrada e os personagens que a vivenciam não necessitam ser validados pela realidade circunstante, são frutos e produtos da ficção.

Já na esfera jornalística, a prática de escrita deve ser voltada à documentação da realidade, porque "depende intensamente da referencialidade, de um espelho de correspondências intrínsecas com a realidade que a linguagem não tem como garantir" (MOURA, 2008, p. 5). Nessa esfera, o escritor deveria, portanto, aperfeiçoar a escrita objetiva, pautar-se na realidade cotidiana e circundante, mostrar as diferentes versões dos fatos ocorridos, mas sem se desprender do acontecimento real. Mas não é o que efetivamente acontece nesse gênero, pois segundo Melo (2002) a crônica situa-se na fronteira entre a informação de atualidade e a narração literária, aproximando-se de "um relato poético do real".

Quando a crônica é publicada em jornais de circulação diária e 
de grande circulação, normalmente, ela se destina a um público mais diverso, de perfil variado, supostamente mais distanciado do enunciador. Quando inserida em periódicos semanais ou mensais e ocupando um espaço específico e determinado, há a aproximação do leitor, pois o enunciador tem dele um perfil previamente definido. É, portanto, para esse perfil definido de leitor que os textos publicados na revista Língua Portuguesa se dirigem.

É possível observamos, na materialidade discursiva da seção $O$ português é uma figura, aspectos da crônica, pois o autor-criador narra, utilizando recursos poéticos, acontecimentos reais, dados colhidos a partir do que viu, leu ou ouviu, sobre autores e obras que ainda pertencem ao cotidiano do leitor. $\mathrm{O}$ ato responsivo do autor-criador aparece ao expor esses dados que correspondem à realidade, não só a vivenciada pelos autores, mas que se ressignificam frente à realidade cotidiana tanto do contexto de enunciação na coluna, quanto do contexto de interação do leitor. Desse modo, de forma poética, o autor-criador colhe da história real de vida dos autores, fatos, comportamentos, valores, principalmente, voltados às suas manifestações enunciativas e linguísticas, que promovam, no leitor, reflexões sobre essas manifestações também no seu cotidiano.

Um exemplo, que comprova como as escolhas e abordagens enunciativas do autor-criador podem despertar a curiosidade do leitor e fazê-lo refletir sobre o cotidiano circundante, pode ser visto na Figura 4, seção que trouxe Rolando Boldrin, nome artístico de Cornélio Pires.

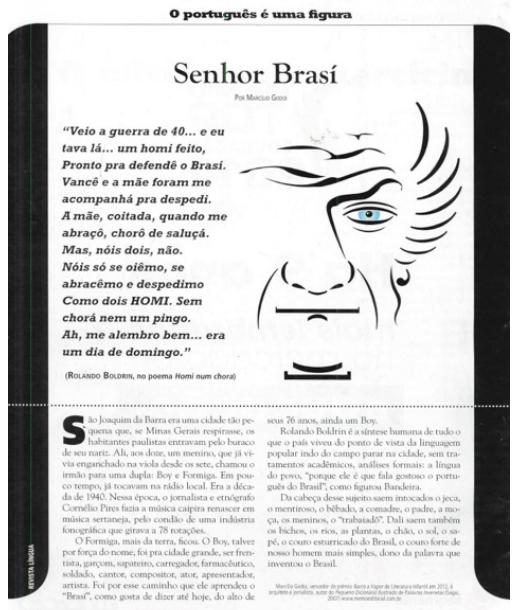

Figura 4.Fonte: GODOI, M. Senhor Brasí. In: O português é uma figura. Língua Portuguesa. Ano III, n.33. p. 66. 
O autor-criador nos apresenta Boldrin como um homem que deixou a pequena cidade de São Joaquim da Barra para se aventurar na cidade grande, "para ser frentista, garçom, sapateiro, carregador, farmacêutico, soldado, cantor, compositor, ator, apresentador, artista" (Fig. 4). As experiências de vida e profissionais destacadas pelo autorcriador foram, segundo ele, relevantes à formação pessoal e intelectual do compositor, já que o permitiram conhecer várias facetas do homem brasileiro e aprender "o Brasí", ou seja, a essência do que é ser brasileiro - a língua. É, pois, a identidade linguística das composições de Rolando Boldrin que despertou o projeto de dizer do autor-criador e levou-o a criar o título da seção: "Senhor Brasí", já que o autor-criador o compreende como o "dono da palavra que inventou o Brasil" (Fig. 4).

O fragmento baixo, citado na seção ao lado do desenho, foi extraído da canção "Homi num chora", de Rolando Boldrin.

\author{
Veio a guerra de $40 \ldots$ e eu \\ Tava lá... um homi feito, \\ Pronto pra defende o Brasí. \\ Vancê e a mãe foram me \\ Acompanha pra despedi. \\ A mãe, coitada, quando me \\ Abraço, choro de saluçá \\ Mas, nóis dois, não. \\ Nóis só se oiêmo, se \\ Abracêmo e despedimo \\ Como dois HOMI. Sem \\ Chorá nem um pingo. \\ Ah, me alembro bem... era \\ Um dia de domingo (Fig. 4).
}

O autor-criador escolhe esse fragmento para ilustrar o estilo das composições de Rolando Boldrin. A letra da música enfatiza uma linguagem coloquial e regionalista, em que há a supressão e a troca de alguns fonemas, a fim de proporcionar a musicalidade própria da língua falada do português no Brasil. Também aborda valores sociais, pois homem não pode demonstrar sentimento. Veja que homem (HOMI) foi grafado com letra maiúscula para enfatizar seu papel na sociedade: forte, corajoso, bravio. Logo, o compositor é, segundo o projeto de dizer do autor-criador, "Senhor Brasí" por mostrar, em suas composições, a brasilidade linguística, própria da comunicação no cotidiano, e os valores sociais que imperam nesse país. 
Rolando Boldrin é a síntese humana de tudo o que o país viveu do ponto de vista da linguagem popular indo do campo parar na cidade, sem tratamentos acadêmicos, análises formais: a língua do povo, "porque ele é que fala gostoso o português do Brasil", como figurou Bandeira (Fig. 4).

Assim, ao falar sobre Rolando Boldrin, apresentar as características de sua obra, suas experiências de vida e suas escolhas enunciativas, o autor-criador, leva-nos, além de conhecer aspectos sobre a vida e obra do autor/compositor, observar comportamentos sociais na atualidade, como o machismo ainda existente na sociedade brasileira, bem como as mais simples manifestações da linguagem cotidiana que são, muitas vezes, ridicularizadas pelo preconceito linguístico, mas que efetivamente representam a identidade do povo brasileiro.

Vimos que a seção O português é uma figura participa das reflexões sobre a língua/linguagem a que o periódico se propõe. Logo, tem-se estabelecido o perfil de seu leitor - um sujeito interessado em conhecer diferentes mecanismos da língua portuguesa - e sabe-se o que ela pretende enunciar e levá-lo a pensar - a língua em diferentes situações de comunicação e modalidades discursivas que configuram o homem e o mundo em diferentes momentos enunciativos.

Por essas características e projeto de dizer da seção, como vistas na seção que trouxe Adoniran Barbosa, constatamos a presença de um enunciador observador do cotidiano e dos costumes que nos mostra a realidade circundante e nos faz pensar e refletir sobre ela. Esse enunciador nos evidencia atos responsivos que caracterizam os diálogos com o gênero crônica.

\section{CONSIDERAÇÕES FINAIS}

Após exploradas e destacadas as particularidades enunciativas dos gêneros biografia, perfil, reportagem e crônica, observamos que esses gêneros dialogam entre si quando expostos na esfera jornalística. Todos eles praticam o ato de narrar, nem sempre de forma objetiva, um acontecimento da vida cotidiana, o qual, de forma direta ou indireta, explícita ou implícita, promove uma reflexão sobre ela e a ressignifica por meio de um novo contexto, do foco narrativo e das escolhas enunciativas. São, portanto, gêneros que dialogam com outras áreas do conhecimento como a história, a literatura e o jornalismo, bem como com outros gêneros discursivos comuns que carregam em si valores ideológicos comuns à esfera jornalística - difundir acontecimentos da realidade cotidiana, por meio de relato, interpretação, análise e reflexão. 
No processo investigativo, apontamos o caráter jornalístico da seção ao reconhecermos elementos enunciativos próprios dessa esfera, como a atualização dos enunciados e sua periodização. Também ressaltamos, na materialidade da seção, diálogos com os gêneros biografia e perfil biográfico, visto que um dos objetivos da seção é traçar o perfil de um artista ou escritor de língua portuguesa; e com os gêneros reportagem e crônica, já que, ao traçar o perfil do autor, há uma narrativa sumarizada de parte de sua vida e de sua obra, bem como a contextualização com o cotidiano enunciado.

O entrelaçamento de gêneros acontece devido às formas de circulação da seção. Ela está inserida na esfera jornalística, mas dialoga com as esferas científica e educacional, por isso, não pode ser determinada como um único gênero discursivo - biografia, perfil, crônica, reportagem, material didático. Carrega marcas enunciativas dos gêneros com os quais ela dialoga em sua forma de construção que envolve produção, leitura, especificidades temáticas e estilísticas.

\section{REFERÊNCIAS}

BAKHTIN, M. Estética da criação verbal. Trad. Maria Ermantina Galvão. 3.ed. São Paulo: Martins Fontes, 2000.

. A crônica. In: CASTRO, G.; GALENO, A. (Orgs) Jornalismo e Literatura: a sedução da palavra. São Paulo, Escrituras, 2002.

BAKHTIN, M.NOLOCHÍNOV, V.N. Marxismo e filosofia da linguagem. 14. ed. São Paulo: Editora Hucitec, 2010.

BRAIT, B.; PISTORI, M.H.C. A produtividade do conceito de gênero em Bakhtin e o círculo. ALFA: Revista de linguística, São Paulo, 56 (2) 371-401. 2012. Disponível em: http://seer.fclar.unesp.br/alfa/article/view/5531 Acesso em: 20 fev. 2015.

COSTA, C. P. A. Escritores jornalistas no Brasil 1904-2004. São Paulo: Companhia das Letras, 2005.

CRISTÓVÃO, A. Fazendo gênero em jornalismo: os projetos editoriais da Folha de São Paulo em perspectiva dialógica. 2011. Disponível em:

DIAS, L. F. Texto, escrita, interpretação: ensino e pesquisa. João Pessoa: Ideia, 2001.

FONSECA, V. P. S.; VIEIRA, K. M. A biografia como acontecimento jornalístico. LíberoSão Paulo - v.14, n.28, p. 99-108, dez. 2011. Disponível em:

GRILLO, S. V. de C. Esfera e campo. In: BRAIT, B. (Org.) Bakhtin: outros conceitos-chave. São Paulo: Contexto, 2006.

GULLAR, F. Traduzir-se. In: Cadernos de literatura brasileira. n. 6. Rio de Janeiro: Instituto Moreira Salles, set. 1998. 
HOUAISS, A; VILLAR, M S.; FRANCO, F.M.M. Dicionário Houaiss da língua portuguesa. Rio de Janeiro: Objetiva, 2009.

http://casperlibero.edu.br/wp-content/uploads/2014/05/6-A-biografia-comoacontecimento-jornal\%C3\%ADstico.pdf Acesso em: 20 mar. 2015.

http://portal.fclar.unesp.br/poslimpor/teses/Assuncao_Cristovao.pdf. Acesso em: 10 fev. 2015.

MELO, J. M. A opinião no jornalismo brasileiro. São Paulo: Vozes, 1985

MENDONÇA, M.C.; CAVALCANTI, J. R. Marcas de estilo em gêneros da esfera jornalística. 2011. Disponível em: www.cchla.ufrn.br/.../Marina\%20Celia\%20 Mendonça\%20\%28UNESP-\%20. Acesso em: 19 fev. 2015.

MOURA, S. A. A crônica: entre o campo literário e o campo jornalístico. 2008. Disponível em: www.contemporane.uerj.br/pdf/ed_11/contemporanea_n11_02_sergio_arruda.pdf. Acesso em: 20 abr. 2015.

Recebido em: 15/06/2019

Aceite em: 16/06/2019 